Tropical Journal of Pharmaceutical Research April 2015; 14 (4): 671-677

ISSN: $1596-5996$ (print); 1596-9827 (electronic)

(C) Pharmacotherapy Group, Faculty of Pharmacy, University of Benin, Benin City, 300001 Nigeria.

All rights reserved.

Available online at http://www.tjpr.org

Original Research Article

http://dx.doi.org/10.4314/tjpr.v14i4.16

\title{
Optimization, Validation and Application of Spectrophotometric Assay for 3-Hydroxy-3-methylglutaryl- coenzyme A Reductase Activity
}

\author{
Gai Liang ${ }^{1,2}$, Hao Kou ${ }^{2}$, Ting-ting Wang ${ }^{2}$, Yu Guo ${ }^{2}$, Jie Ping ${ }^{2,3}$ and Hui Wang ${ }^{2,3 *}$ \\ ${ }^{1}$ Department of Oncology, First Affiliated Hospital of Yangtze University, Jingzhou, Hubei, 44300, ${ }^{2}$ Department of \\ Pharmacology, Basic Medical School, ${ }^{3}$ Research Center of Food and Drug Evaluation, Wuhan University, Wuhan 430071, \\ China
}

*For correspondence: Email: wanghui19@whu.edu.cn; Tel: +86-27-68758665; Fax: +86-27-68759222

Received: 9 January 2015

Revised accepted: 24 March 2015

\begin{abstract}
Purpose: To improve the sensitivity and specificity of spectrophotometric 3-hydroxy-3-methylglutarylcoenzyme A (HMG-CoA) reductase activity assay.

Methods: Spectrophotometric HMG-CoA reductase detection in male Wistar rat liver microsomes was optimized by applying different conditions, such as reaction buffer $\mathrm{pH}$, NADPH and protein concentration, and preincubation and reaction times. The optimal set of conditions was validated using HMG-CoA reductase inhibitors, namely, pravastatin, fluvastatin, and rosuvastatin. IC $C_{50}$ was calculated and compared with that of a radiochemical assay. Ginkgo biloba extract's (GBE50) inhibitory effect on HMG-CoA reductase activity was evaluated using the optimized spectrophotometric protocol.

Results: The optimum assay conditions were as follows: reaction buffer $p H$ 7.0, $100 \mu M$ NADPH, 50 $\mu M$ HMG-CoA, and $200 \mu \mathrm{g} / \mathrm{mL}$ microsomal protein. The preincubation and reaction times were 20 and $60 \mathrm{~min}$, respectively, at $37^{\circ} \mathrm{C}$. The IC 50 of pravastatin, fluvastatin, and rosuvastatin under the optimum condition was 0.026, 0.015, and $0.007 \mu \mathrm{M}$ while for radioisotope assay, it was 0.034, 0.049 and 0.0119 $\mu M$, respectively. GBE50 significantly inhibited HMG-COA reductase activity in a concentrationdependent manner $(p<0.05)$.

Conclusion: These results suggest that HMG-CoA reductase activity can be detected using the improved spectrophotometric assay. This assay can facilitate the discovery and development of new HMG-CoA reductase inhibitors in vitro.
\end{abstract}

Keywords: Spectrophotometry, 3-Hydroxy-3-methylglutaryl-coenzyme A reductase activity, Cholesterol metabolism, Ginkgo biloba, Pravastatin, Fluvastatin, Rosuvastatin

Tropical Journal of Pharmaceutical Research is indexed by Science Citation Index (SciSearch), Scopus, International Pharmaceutical Abstract, Chemical Abstracts, Embase, Index Copernicus, EBSCO, African Index Medicus, JournalSeek, Journal Citation Reports/Science Edition, Directory of Open Access Journals (DOAJ), African Journal Online, Bioline International, Open-J-Gate and Pharmacy Abstracts

\section{INTRODUCTION}

Mevalonic acid (MVA) is an important biochemical intermediate in cholesterol synthesis. High circulating cholesterol levels may induce atherosclerosis, which contributes to the occurrence of cardiovascular and cerebrovascular disorders and diseases, such as hypertension, coronary heart disease, thrombosis, and cerebral hemorrhage [1].

3-Hydroxy-3-methylglutaryl-coenzyme A (HMG$\mathrm{CoA}$ ) reductase is the rate-limiting enzyme in the MVA to cholesterol biotransformation pathway. Accordingly, it plays a significant role in cholesterol homeostasis [2]. Although methods to determine HMG-CoA reductase mRNA and 
protein expression in various regulatory mechanisms are well established [3], a sensitive, economical HMG-CoA reductase activity assay has not been developed. HMG-CoA reductase activity is conventionally assayed using elaborate radiochemical techniques [4], chromatographic techniques coupled with mass spectrometry (LC/MS) [5], or spectrophotometrically monitoring the decrease in the cofactor NADPH absorbance at $340 \mathrm{~nm}$ [6].

The radiolabeled assay is limited for several reasons, including the use of radioactive substances, the complicated procedure, the potential for radioactive contamination, and the high cost. LC/MS requires advanced and expensive instruments, which limits its use as a routine laboratory technique. Compared with these methods, spectrophotometry is rapid and simple. There is no need to separate the products or handle radioactive materials. Moreover, spectrophotometers are standard laboratory equipment, making them easily accessible. However, spectrophotometric assays do have some disadvantages. They are subject to high background NADPH hydrolysis if the protein sample comes from whole cells or purified organelles, and protein purification is complicated and expensive. If an optimized spectrophotometric assay that is both sensitive and simple were developed, it would be of great importance in basic and pharmacological research on cholesterol metabolism.

HMG-CoA reductase inhibitors effectively reduce cholesterol biosynthesis, which makes them valuable hypolipidemic agents and the drugs of choice for atherosclerosis. Thus, a large number of studies investigating HMG-CoA reductase inhibitors are underway to identify candidate drugs for treating hypercholesterolemic disorders [7].

The objective of this study was to develop an improved spectrophotometric HMG-CoA reductase activity assay by optimizing key factors in the reaction condition. Furthermore, we evaluated the HMG-CoA reductase inhibitory effects of Ginkgo biloba extract (GBE50), which has been implicated in cholesterol metabolism modulation $[8,9]$, using the improved spectrophotometric technique.

\section{EXPERIMENTAL}

\section{Chemicals and materials}

Colestyramine was purchased from Life-care Pharmaceutical Co. (Nanjing, China), and NADPH was from Beyotime Biotechnology Co.
(Shanghai, China). HMG-CoA, Pravastatin, Fluvastatin and Rosuvastain were purchased from Sigma-Aldrich (St. Louis, MO, USA). [14C]HMG-CoA and [14C]-Mevalonolactone (2.14 $\mathrm{GBq} / \mathrm{mmoL}$ ) were obtained from GE Healthcare Life Sciences (Buckinghamshire, UK). GBE50 was purchased from XingLing Pharmaceutical Co. (Shanghai, China). All other chemicals and reagents were analytical grade.

\section{Animals}

The animal studies were approved by Ethics Committee of Wuhan University, and the study protocol was in accordance with the guidelines for the Care and Use of Laboratory Animals of the Chinese Animal Welfare Committee. Male Wistar rats $(220-250 \mathrm{~g})$ were obtained from the Experimental Center of Hubei Medical Scientific Academy (China, no. 2006-0005). The animals were housed in a light-controlled room with the dark period from 7:00 AM to 7:00 PM, and fed ad libitum with $2 \%$ cholestyramine-supplemented powdered diet for 6 days to achieve maximal liver HMG-CoA reductase activity [10]. The animals were anesthetized using isoflurane and sacrificed by decapitation at 10:00 AM on the sixth day, and the liver were isolated, weighed, and immediately stored at $-80{ }^{\circ} \mathrm{C}$ until subsequent analysis.

\section{Liver microsome preparation}

Rats liver microsomes were prepared by homogenization and differential centrifugation using established protocols [11]. In brief, the tissues were homogenized in three-fold volume ice-cold homogenization buffer A (100 mM sucrose, $50 \mathrm{mM} \mathrm{KCl}, 40 \mathrm{mM}$ potassium phosphate, $30 \mathrm{mM}$ potassium EDTA, pH 7.2) with a motor-driven, glass-Teflon PotterElvehjem homogenizer (JingKe Chemical Co., Shanghai). The homogenate was centrifuged for $15 \mathrm{~min}$ at $12,000 \times \mathrm{g}$, the supernatant was removed and centrifuged again for $15 \mathrm{~min}$ at $12,000 \times \mathrm{g}$, and the resultant supernatant was centrifuged for $60 \mathrm{~min}$ at $100,000 \times \mathrm{g}$. The pellets were resuspended in buffer $A$ and centrifuged at $100,000 \times \mathrm{g}$ for $60 \mathrm{~min}$. Following that, the pellets were resuspended in buffer $B$ (buffer $A$ plus $10 \mathrm{mM}$ dithiothreitol) using a hand-driven, all-glass Potter-Elvehjem homogenizer to prepare microsomal suspension. All of the operations were performed at $4{ }^{\circ} \mathrm{C}$. The final suspension was stored at $-20^{\circ} \mathrm{C}$.

\section{HMG-CoA reductase solubilization}

The Beg $\mathrm{ZH}$ method was used to solubilize the enzyme [11]. The microsomal suspension was 
thawed at $37{ }^{\circ} \mathrm{C}$ water and an equal volume of buffer B supplemented with $50 \%$ glycerol and preheated to $37{ }^{\circ} \mathrm{C}$ was added. The mixture was homogenized thoroughly with a hand-driven, all glass Potter-Elvehjem homogenizer and incubated at $37{ }^{\circ} \mathrm{C}$ for $60 \mathrm{~min}$. The suspension was diluted three-fold with buffer $B$, homogenized again, and then centrifuged at $100,000 \times \mathrm{g}$ for $60 \mathrm{~min}$ at $25^{\circ} \mathrm{C}$. The supernatant containing solubilized HMG-CoA reductase was used for the activity assay. The supernatant protein concentration was determined using the Bradford method [12], and the protein concentration was adjusted to $1 \mathrm{mg} / \mathrm{mL}$.

\section{Spectrophotometric HMG-CoA reductase activity assay}

The HMG-CoA reductase activity was determined spectrophotometrically using previously published protocols $[7,13]$ with some modifications. Briefly, the total reaction volume was $1 \mathrm{~mL}$. The reaction was preincubated at 37 ${ }^{\circ} \mathrm{C}$. Both the microsomal protein (total protein concentration $200 \mu \mathrm{g} / \mathrm{mL}$ ) and $100 \mu \mathrm{M}$ NADPH were added to buffer $\mathrm{C}(0.2 \mathrm{M} \mathrm{KCl}, 0.16 \mathrm{M}$ potassium phosphate, $0.004 \mathrm{M}$ EDTA, and 0.01 $M$ dithiothreitol). The reaction was initiated with $50 \mu \mathrm{M}$ HMG-CoA and was allowed to proceed for $60 \mathrm{~min}$. When the reaction finished, the optical density at $340 \mathrm{~nm}$ was measured using a UV1601 spectrophotometer (Shimadzu, Japan). One unit of enzyme activity was defined as the amount of NADPH consumed by $1 \mathrm{mg}$ enzyme per minute. The system was validated via inhibition studies using three HMG-CoA reductase inhibitors: pravastatin, fluvastatin and rosuvastatin.

\section{Radiochemical HMG-CoA reductase activity assay}

To validate the optimized spectrophotometric assay, an adaptation of the radiochemical method described previously [14] was used to compare HMG-CoA reductase activity inhibition by pravastatin, fluvastatin and rosuvastatin (positive controls). A $120-\mu \mathrm{L}$ reaction volume consisted of the microsomal protein and 500 $\mathrm{nmoL}$ of NADPH (dissolved in the reaction buffer containing $0.1 \mathrm{M}$ of triethanolamine and $10 \mathrm{mM}$ of EDTA). The reaction was preincubated at 37 ${ }^{\circ} \mathrm{C}$ for $5 \mathrm{~min}$. Then the drug inhibition was evaluated using different concentrations: pravastatin $(1.3,12.9$, and $129 \mu \mathrm{g} / \mathrm{L})$, fluvastatin $(0.7,7.7$, and $77.4 \mu \mathrm{g} / \mathrm{L})$ and rosuvastatin $(0.3$, 3.2 , and $32.3 \mu \mathrm{g} / \mathrm{L})$.

The reaction was initiated with $5.17 \mathrm{nmoL}$ of [14C]-HMG-CoA. The reaction proceeded for 15 min at $37^{\circ} \mathrm{C}$ and terminated by the addition of 30 $\mu \mathrm{L}$ of $6 \mathrm{M} \mathrm{HCl}$. The resultant mixture was incubated at $37^{\circ} \mathrm{C}$ for another $15 \mathrm{~min}$ to allow the MVA to convert to mevalonolactone. The incubation mixture was centrifuged at $10,000 \mathrm{~g}$ for $5 \mathrm{~min}$, and the supernatant was directly spotted on a Silica Gel 60 F254 TLC plate (Merck, Germany). The plate was developed in benzene:acetone $(1: 1, \mathrm{v} / \mathrm{v})$.

Finally, the $\mathrm{Rf} 0.5-0.9$ region was removed by scraping using a clean razor blade, and the [14C] radioactivity determined using a liquid scintillation counter. [14C]-mevalonolactone was used as a standard. The $50 \%$ inhibitory concentration $\left(\mathrm{IC}_{50}\right)$ of the three drugs was calculated using the Statistical Package for Social Sciences (SPSS 17.5) software package.

\section{Inhibitory effect of GBE50 on HMG-CoA reductase activity}

GBE50's inhibitory effect in different concentrations $(32.26,322.6$, and $3226 \mu \mathrm{g} / \mathrm{L})$ on HMG-CoA reductase activity was tested using the optimized spectrophotometric assay.

\section{Statistical analysis}

The data were expressed as mean \pm SD. SPSS 17.5 software was used for data analysis. Analysis of variance (one-way ANOVA) was used to compare the means of different groups. Statistical significance was defined as $p<0.05$.

\section{RESULTS}

\section{Reaction buffer $\mathrm{pH}$ and preincubation and reaction time duration}

The $\mathrm{pH}$ of the spectrophotometric reaction buffer, buffer $\mathrm{C}$, was adjusted to five different values: $6.0,6.5,7.0,7.5$, and 8.0 and the activity was assayed. The activity increased initially but decreased when the reaction buffer $\mathrm{pH}$ value was greater than 7.0. Accordingly, the optimal reaction buffer $\mathrm{pH}$ for maximum reductase activity was 7.0 (Fig 1A, p<0.05 vs. pH 6.5).

The reaction mixtures with $200 \mu \mathrm{g}$ microsomal protein were preincubated with $100 \mu \mathrm{M}$ NADPH at $37^{\circ} \mathrm{C}$ for $0-40 \mathrm{~min}$ prior to the addition of 50 $\mu \mathrm{M}$ HMG-CoA (Fig. 1B). The reaction proceeded for $40 \mathrm{~min}$ at $37^{\circ} \mathrm{C}$. HMG-CoA reductase activity slightly increased with increased preincubation time then decreased. Peak activity occurred at a preincubation time of approximately $20 \mathrm{~min}(\mathrm{p}<$ 0.05 vs. 0 min). 
The reductase activity increased linearly with increased reaction time until $60 \mathrm{~min}$ and then plateaued. Therefore, the optimal reaction time was $60 \mathrm{~min}$ (Fig 1C, $p<0.05$ vs. $50 \mathrm{~min}$ ).

\section{NADPH and microsomal protein concentration}

There was an approximately linear increase in reductase activity with increased microsomal protein concentrations, and a microsomal protein concentration of $200 \mu \mathrm{g} / \mathrm{mL}$ was an appropriate concentration to obtain higher HMG-CoA reductase activity (Fig 2B, $p<0.05$ vs. $50 \mu \mathrm{g} / \mathrm{L}$ ).
Validation and application of the optimized assay

\section{Assay of three known HMG-CoA reductase inhibitors}

All the three drugs, pravastatin, fluvastatin and rosuvastatin, inhibited HMG-CoA reductase activity in a concentration-dependent manner, and the linear correlations ( $r$ values) were 0.999 (Fig 3A), 0.98 (Fig 3B) and 0.87 (Fig 3C), respectively. The $\mathrm{IC}_{50}$ of pravastatin, fluvastatin and rosuvastatin were $0.026,0.015$ and 0.0066 $\mu \mathrm{M}$, respectively.
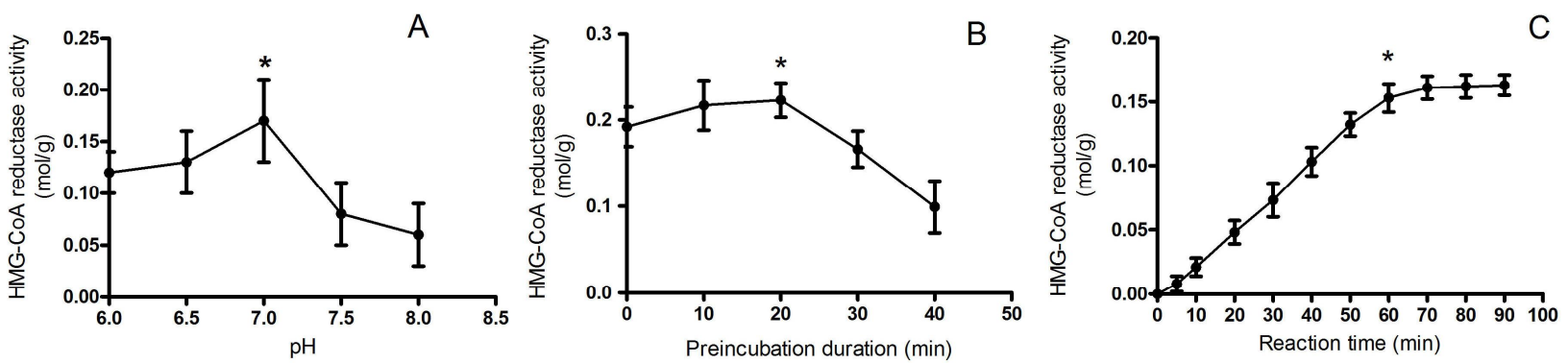

Figure 1: Effects of different reaction buffer $\mathrm{pH}(\mathrm{A})$, preincubation duration $(\mathrm{B})$ and reaction time $(\mathrm{C})$ on 3hydroxy-3-methylglutaryl-coenzyme A (HMG-CoA) reductase activity. Data are presented as mean $\pm \mathrm{SD}, \mathrm{n}=5 ;{ }^{*} p$ $<0.05$ vs control group
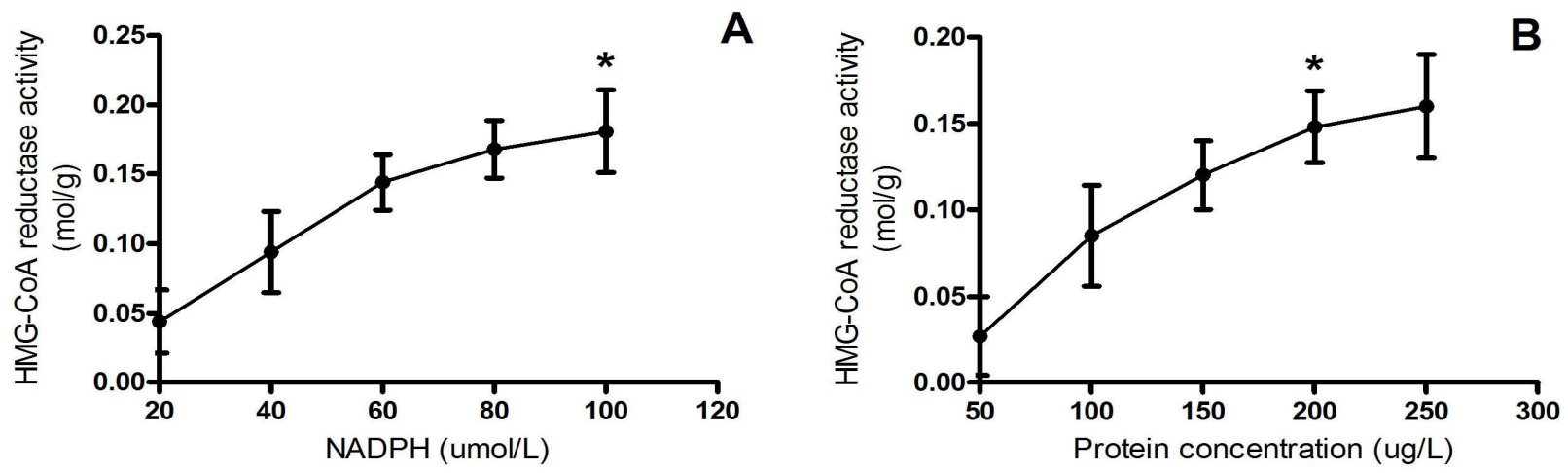

Figure 2: Effects of NADPH concentration (A) and microsomal protein concentration (B) on HMG-CoA reductase activity. Data points are mean $\pm \operatorname{SD}(n=5) ;{ }^{*} p<0.05$ vs control group
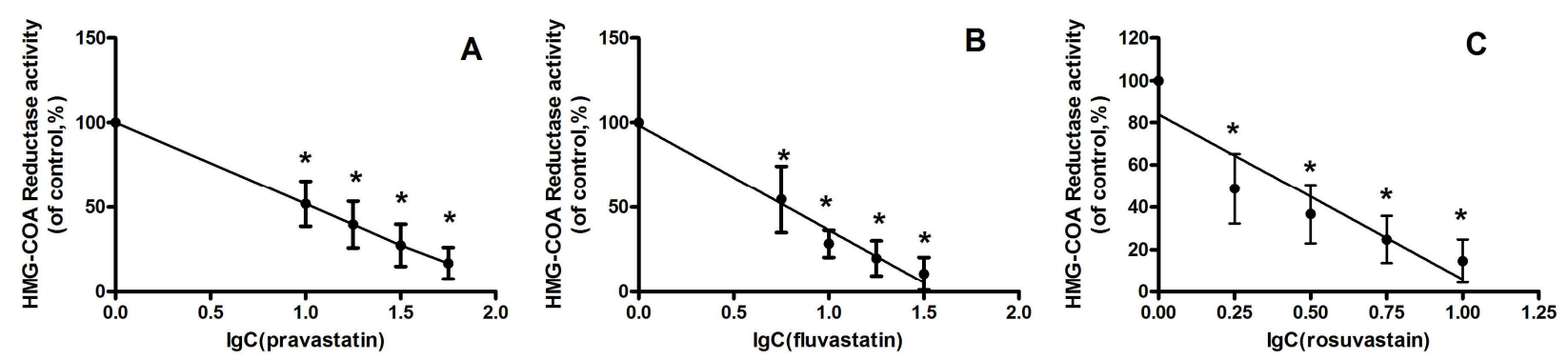

Figure 3: Pravastatin (A), fluvastatin (B), and rosuvastatin (C) inhibition of HMG-CoA reductase activity detected using the optimized spectrophotometric assay. Data points are mean $\pm S D(n=5) ;{ }^{*} p<0.05$ vs. control group 

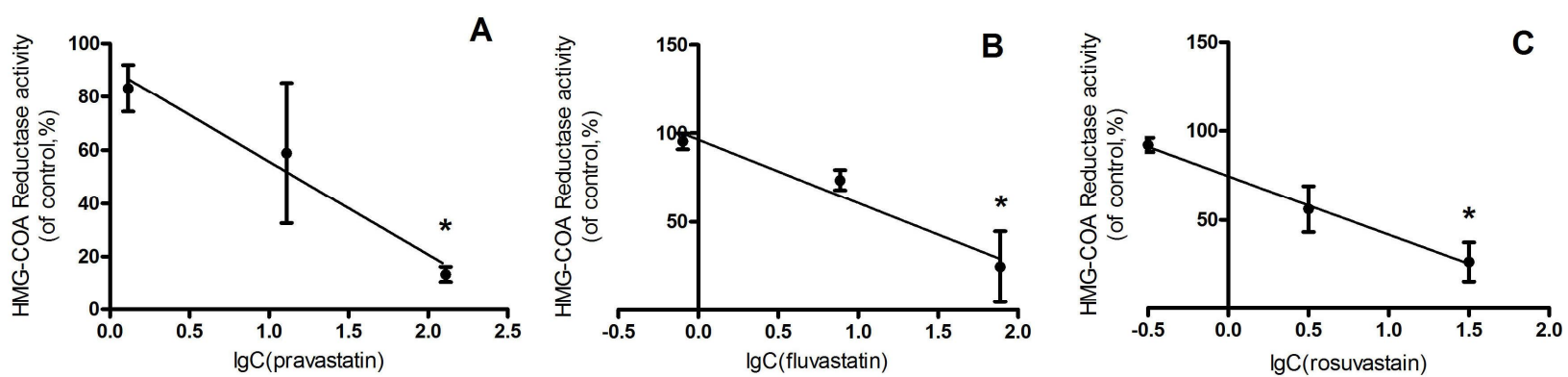

Figure 4: Inhibitory effect of pravastatin (A), fluvastatin (B), and rosuvastatin (C) inhibition of HMG-CoA reductase activity detected using a radioisotope assay. Data points are expressed as mean \pm SD $(n=5) ;{ }^{*} p<$ 0.05 vs. control group (pravastatin $1.3 \mu \mathrm{g} / \mathrm{L}$, fluvastatin $0.7 \mu \mathrm{g} / \mathrm{L}$, and rosuvastatin $0.3 \mu \mathrm{g} / \mathrm{L}$ )

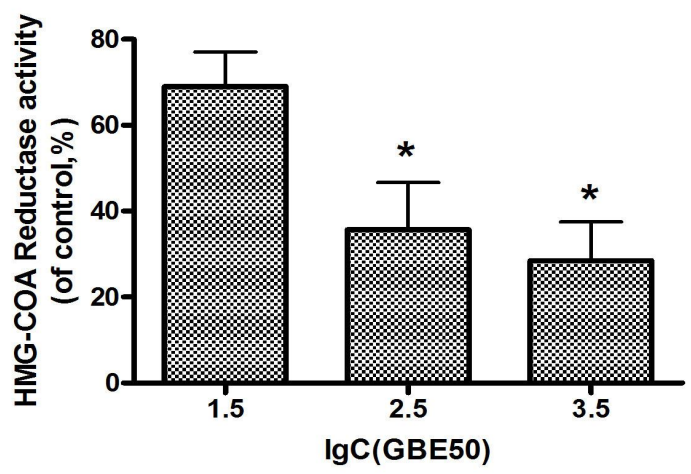

Figure 5: Effect of Ginkgo biloba extract (GBE50) on HMG-CoA reductase activity. Data points are expressed as mean $\pm \operatorname{SD}(\mathrm{n}=5) ;{ }^{*} p<0.05$ vs control group

We also evaluated the three inhibitors using a radioisotope assay. There was a linear relationship between HMG-CoA reductase inhibition and drug concentration for all three known inhibitors, and the $r$ values were 0.985 , 0.976 , and 0.999 , respectively (Fig 4). The $I_{50} \mathrm{~S}$ of pravastatin, fluvastatin, and rosuvastatin from the radioisotope assay were as follows: 0.0343 , 0.0485 , and $0.0119 \mu \mathrm{M}$, respectively.

\section{Application of the optimal spectropho- tometric assay}

GBE50 inhibited HMG-CoA reductase activity in a concentration-dependent manner (Fig 5, p < 0.05).

\section{DISCUSSION}

Over the years, the major shortcomings of the spectrophotometric HMG-CoA reductase activity assay have been identified. Direct spectrophotometric NADPH oxidation determination is readily subject to interference by other NADPH-expending reactions, and these non-specific reactions produce excess background making the measurements inaccurate [15]. Rat liver microsomes, the enzyme source in this study, contain complex NADPH-dependent enzymatic systems that consist of HMG-CoA and others (e.g. HMG-CoA lyase) [16]. Therefore, it is important to improve the spectrophotometric accuracy by eliminating non-specific NADPH consumption that not derived from HMG-CoA. Previous studies obtained high HMG-CoA reductase activity using a complicated and expensive purification technique [17]. There is still a need for a simple and rapid HMG-CoA reductase activity assay.

In this study, we optimized several reaction variables including the reaction buffer $\mathrm{pH}$, the preincubation and reaction duration, and substrate and microsomal protein concentrations. We employed the basic principles of optimization.

First, we adjusted each variable independently while keeping all others fixed to achieve the highest HMG-CoA reductase activity. Once the optimized variable was determined, it would be applied to the subsequent reaction system optimization experiments.

Our results showed that the optimal spectrophotometric HMG-CoA reductase activity assay conditions are as follows: reaction buffer $\mathrm{pH}$ 7.0, containing $100 \mu \mathrm{M}$ NADPH and 200 $\mu \mathrm{g} / \mathrm{mL}$ microsomal protein, incubating the protein and NADPH for $20 \mathrm{~min}$ at $37^{\circ} \mathrm{C}$ prior to $50 \mu \mathrm{M}$ HMG-CoA addition, and reacting for $60 \mathrm{~min}$ at 37 ${ }^{\circ} \mathrm{C}$. High HMG-CoA reductase activity was obtained in these conditions. The HMG-CoA reductase specific activity was approximately 160 $\mu \mathrm{moL}$ NADPH oxidized/min॰mg microsomal protein under the optimal condition.

To validate this spectrophotometric assay system, we compared the kinetic results from our 
optimized spectrophotometric assay with a radioisotope assay using three known HMG-CoA reductase inhibitors (pravastatin, fluvastatin and rosuvastatin). Our results showed that the $I_{50} \mathrm{~S}$ of the known inhibitors calculated using the improved spectrophotometric assay are the same order of magnitude as those obtained using a radioisotope assay. The GBE50 inhibition of HMG-CoA reductase activity was evaluated using the optimal spectrophotometric assay. GBE50 demonstrated concentration-dependent inhibition of HMG-CoA reductase activity. This result is consistent with our previously study using a radioisotope assay [18].

Recently, a HMG-CoA reductase assay kit became commercially available (Sigma-Aldrich, St. Louis, MO, USA). The kit provides the human enzyme catalytic domain (HMGR; recombinant GST fusion protein expressed in $E$. coli), and it has been used in some studies [19]. The assay also spectrophotometrically measures the absorbance decrease at $340 \mathrm{~nm}$, which represents NADPH oxidation by HMGR in the presence of the HMG-CoA substrate.

However, according to the manufacturer's documentation, the kit is only designed to screen for different inhibitors/activators of the purified catalytic subunit in vitro (http://www.sigma aldrich.com/china-mainland/zh/technical-docum ents/articles/biofiles/hmg-coa-reductase.html\#M aterials). In vivo, HMG-CoA reductase activity is controlled through synthesis, degradation, and phosphorylation in order to maintain the appropriate mevalonate-derived product concentrations. This regulation plays a vital role in hepatic lipid metabolism, especially for cholesterol metabolic pathway. Therefore, an accurate HMG-CoA reductase activity assay using whole protein from animals or tissues is imperative for investigating cholesterol homeostasis disturbance mechanisms and associated diseases, such as hypercholesterolemia.

Unfortunately, a well-developed, simple, rapid, and accurate method for assaying HMG-CoA reductase activity in these types of samples has not yet been achieved. For example, Rao et al described an indirect HMG-CoA reductase activity assessment in liver tissue [20], which is still being used by many investigators. Therefore, because the optimized spectrophotometric HMGCoA reductase activity assay presented here is based on rat liver microsomes, it offers a new alternative for assessing tissue-derived whole protein, which would be valuable for investigating cholesterol metabolism in liver tissue. In addition, by using different enzyme sources (i.e. commercial human or animal microsomes), this improved method could also be used to screen candidate HMG-CoA reductase inhibitors in a simple, rapid, and low cost manner.

\section{CONCLUSION}

An improved spectrophotometric HMG-CoA reductase activity assay has been successfully developed by optimizing different variables relating to the reaction conditions, including preincubation of the enzyme and cofactor prior to HMG-CoA addition. This optimal method is rapid, simple and relatively low cost. It overcomes the low specificity and sensitivity associated with existing spectrophotometric methods, while maintaining a relatively high HMG-CoA reductase activity and greatly increasing hypolipidemic agent screening efficiency. Therefore, this improved spectrophotometric assay provides an alternative technique for studying cholesterol metabolism and favorable HMG-CoA reductase inhibitor screening system in vitro.

\section{REFERENCES}

1. Steinberg D. Atherogenesis in perspective: hypercholesterolemia and inflammation as partners in crime. Nat Med 2002; 8: 1211-1217.

2. Roitelman J, Bar-Nun $S$, Inoue $S$, Simoni RD. Involvement of calcium in the mevalonateaccelerated degradation of 3-hydroxy-3methylglutaryl-CoA reductase. J Biol Chem 1991; 266: 16085-16091.

3. Pallottini V, Guantario B, Martini C, Totta P, Filippi I, Carraro F, Trentalance A. Regulation of HMG-CoA reductase expression by hypoxia. J Cell Biochem 2008; 104: 701-709.

4. Natali F, Siculella L, Salvati S, Gnoni GV. Oleic acid is a potent inhibitor of fatty acid and cholesterol synthesis in C6 glioma cells. J Lipid Res 2007; 48: 1966-1975.

5. Honda A, Mizokami Y, Matsuzaki Y, Ikegami T, Doy M, Miyazaki H. Highly sensitive assay of HMG-CoA reductase activity by LC-ESI-MS/MS. J Lipid Res 2007; 48: 1212-1220.

6. Edwards PA, Lemongello D, Fogelman AM. Improved methods for the solubilization and assay of hepatic 3hydroxy-3-methylglutaryl coenzyme A reductase. J Lipid Res 1979; 20: 40-46.

7. Sadowitz B, Maier KG, Gahtan V. Basic science review: Statin therapy--Part I: The pleiotropic effects of statins in cardiovascular disease. Vasc Endovascular Surg 2010; 44: 241-251.

8. Lin SJ, Yang TH, Chen YH, Chen JW, Kwok CF, Shiao MS, Chen YL. Effects of Ginkgo biloba extract on the proliferation of vascular smooth muscle cells in vitro and on intimal thickening and interleukin-1beta

Trop J Pharm Res, April 2015; 14(4): 676 
expression after balloon injury in cholesterol-fed rabbits in vivo. J Cell Biochem 2002; 85: 572-582.

9. Yao ZX, Han Z, Drieu K, Papadopoulos V. Ginkgo biloba extract (Egb 761) inhibits beta-amyloid production by lowering free cholesterol levels. J Nutr Biochem 2004; 15: 749-756.

10. Ness GC, Spindler CD, Moffler MH. Purification of 3hydroxy-3-methylglutaryl coenzyme $A$ reductase from rat liver. Arch Biochem Biophys 1979; 197: 493-499.

11. Beg ZH, Stonik JA, Brewer HB. Solubilization of 3hydroxy-3-methylglutaryl coenzyme A reductase from rat and chicken liver microsomes. Anal Biochem 1978; 86: 531-535.

12. Bradford MM. A rapid and sensitive method for the quantitation of microgram quantities of protein utilizing the principle of protein-dye binding. Anal Biochem 1976; 72: 248-254.

13. Kleinsek DA, Ranganathan S, Porter JW. Purification of 3-hydroxy-3-methylglutaryl-coenzyme $A$ reductase from rat liver. Proc Natl Acad Sci U S A 1977; 74: 1431-1435.

14. Kim HK, Jeong TS, Lee MK, Park YB, Choi MS. Lipidlowering efficacy of hesperetin metabolites in highcholesterol fed rats. Clin Chim Acta 2003; 327: 129137.

15. Hulcher $\mathrm{FH}$, Oleson $W H$. Simplified spectrophotometric assay for microsomal 3-hydroxy-3-methylglutaryl CoA reductase by measurement of coenzyme A. J Lipid Res 1973; 14: 625-631.

16. Young NL, Berger B. Assay of S-3-hydroxy-3methylglutaryl-CoA reductase. Methods Enzymol 1981; 71(Pt C): 498-509.

17. Edwards PA, Lemongello, Fogelman AM. Purification and properties of rat liver 3-hydroxy-3-methylglutaryl coenzyme A reductase. Biochim Biophys Acta 1979; 574: 123-135.

18. Xie ZQ, Liang G, Zhang L, Wang $Q, Q u Y$, Gao $Y$, Lin $L B$, Ye S, Zhang J, Wang $\mathrm{H}$, et al. Molecular mechanisms underlying the cholesterol-lowering effect of Ginkgo biloba extract in hepatocytes: a comparative study with lovastatin. Acta Pharmacol Sin 2009; 30: 12621275.

19. Perchellet JP, Perchellet EM, Crow KR, Buszek KR, Brown N, Ellappan S, Gao G, Luo D, Minatoya M, Lushington $\mathrm{GH}$. Novel synthetic inhibitors of 3hydroxy-3-methylglutaryl-coenzyme A (HMG-CoA) reductase activity that inhibit tumor cell proliferation and are structurally unrelated to existing statins. Int $\mathrm{J}$ Mol Med 2009; 24: 633-643.

20. Rao AV, Ramakrishnan $S$. Indirect assessment of hydroxymethylglutaryl-CoA reductase (NADPH) activity in liver tissue. Clin Chem 1975; 21: 15231525. 